\title{
The Boundaries of Funniness and the Dilution of Audience Identity in the Musical-Dramatic Art
}

\author{
Viktor L. Levchenko ${ }^{1}$ \& Nina I. Kovalova ${ }^{2}$ \\ Odessa I.I. Mechnikov National University. Odessa, Ukraine
}

\section{Abstract}

This paper sets out to examine the transformation of comedy in the history of European theatre. Musical performance extends the semiotic space of the original genre into a field of fluid and open meanings and signs incorporating and suggesting many interpretations, some of which are ironic. It is argued in contemporary aesthetics that, on the one hand, art cannot exist without a discourse interpreting it, while on the other, there exists the demand to avoid interpretation, which at once legitimizes the aesthetic effect and castrates the object of art. Provocation is used as an instrument for solving the problems of observing the object of art in a new way and understanding modern reality, and provocation is not complete without irony and self-irony. Wit, irony, and comicality are transformed as fitting into the style of the absurd and deconstructing the border between the funny and the serious. The purpose of such provocations is to put the viewer into a position of uncertainty and aesthetic shock, and this stupor inexorably leads the beholder to encounter the object of art and nurtures a new understanding of their own self. This clash of the spectator's viewpoint created by provocative shows dispossesses theatre productions of the status of "museum exhibits". This paper will examine the organicness of elements of the laughter culture and comic devices for musical and dramatic theatre.

\section{Keywords}

Laughter Culture; Comic; Opera; Ballet; Provocation; Spectator's Identity; Interpretation; Communication; Aesthetic Shock; Meaning

This work is licensed under a Creative Commons «Attribution» 4.0 International License

1 Email: victor_levchenko[at]ukr.net

2 Email: nisa_i_k[at]i.ua 


\section{Границы смешного и расшатывание зрительской идентичности в музыкально-драматическом искусстве}

\section{Левченко Виктор Леонидович ${ }^{1}$ Ковалева Нина Ивановна ${ }^{2}$}

Одесский национальный университет им. И. И. Мечникова. Одесса, Украина

\section{Аннотация}

В статье исследуется трансформация комического в истории европейского театра. Музыкальный перформанс расширяет семиотическое пространство исходного жанра в поле значений и знаков, которые текучи и открыты, содержат и предлагают множество интерпретаций, в том числе иронических. В современной эстетике, с одной стороны, утверждается, что искусство не может существовать без интерпретирующего его дискурса. С другой стороны, существует требование избежания интерпретации, которая в то же время узаконивает эстетический эффект и кастрирует произведение искусства. Провокация используется для решения проблем видения объекта искусства по-новому и понимания современной действительности, и это не обходится без иронии и самоиронии. Остроумие, ирония, комичность трансформируются, вписываясь в стиль абсурда и деконструируя границу между смешным и серьезным. Цель подобных провокаций - ввести зрителя в состояние неуверенности и эстетического шока. Такой ступор неизбежно приводит зрителя к встрече с предметом искусства и позволяет по-новому осознавать самого себя. Столкновение зрительских точек зрения, порожденное провокационными шоу, лишает театральные постановки статуса «музейных экспонатов». В статье рассматривается органичность элементов культуры смеха, рассматриваются юмористические приемы музыкально-драматического театра.

\section{Ключевые слова}

смеховая культура; комическое; опера; балет; провокация; зрительская идентичность; интерпретация; коммуникация; эстетический шок; значение

Это произведение доступно по лицензии Creative Commons «Attribution» («Атрибуция») 4.0 Всемирная

1 Email: victor_levchenko[at]ukr.net

2 Email: nisa_i_k[at]i.ua 


\section{Introduction}

In classical aesthetics, from Aristotle's "Politics" right up to the present day, the understanding of art as giving aesthetic pleasure, nurturing and entertaining, has established itself as an indisputable cultural norm. The emphasis placed on the different aspects of the functions of art has, of course, changed according to prevaling cultural-historical attitudes. Baroque and Rococo, for example, were more oriented towards hedonism and entertainment, while Classicism, Enlightenment and the so-called "natural school" were more oriented towards education, although this did not imply a rejection and neglect of the other functions of art.

The exit from this matrix took place only in the early 20th century, which was presented by avant-garde artistic searches. The principal anti-mimeticity, dehumanization and rejection of the quest for transcendental meanings espoused by these searches overturned the matrix model of understanding art. The description of such a model, which had already become classical for humanitarian discourse, was formulated by José Ortega y Gasset. Characterizing the epoch of Art Nouveau, he highlighted its refusal to pursue general popularity as its significant feature, which, in turn, gives rise to the "aesthetic" elitist formula of "art for art's sake" (l'art pour l'art). The artist thus renounces the role of teacher, educator, prophet, revealing the world of the transcendent and carrying its truths into the profane space of everyday life. This is due to the cultural pivot of the Modern epoch, which in art (as well as in science) is based on a new paradigm that relativizes the claims of absolute significance with the claims of art on its involvement in this world of the Absolute. In this way, the phenomenological attitude to the relativity of existing as one of the variants of the Possible in the field of human experience is realized. This relativism implicitly includes the "urge to understand art simply as a game and nothing else" (Ortega y Gasset, 1972, p. 70).

The modernist trends noted above have not lost their relevance in the postmodernist era - the era of neo-hedonism and a new sensitivity. Today, questions about the status of art, the relationship between elements of the intellectual and the sensual, the serious and the comic in art, and the interpenetration of elitist and egalitarian into aesthetic experience acquire a contrary semantic content.

In this context, our study focuses on how the comic articulates itself in musical and dramatic art, its role in building communication between the "work of art" and the "viewer", the limits of using the comic in modern and post-modern art practices, and how comicality contributes to the retention and/or expansion of the viewer's identity.

\section{Theoretical and methodological background}

In the ontological sense, following Wilhelm Dilthey and Emilio Betti (Betti, 2017), we will understand the term "work of art" as a meaningful form with the principle function of presenting meanings intended for understanding. 
In analyzing audience reception and the relationship between text (work of art) and interpreter (spectator), we proceeded from Betti's concept of "methodological hermeneutics" (Betti, 2017), which saw the hermeneutical act as the interaction of two subjectivities. According to investigator of Betti's hermeneutics E. Borisov, an object of interpretation is not a thing, but "an interlocutor, that is, a participant in the actual subjective life of the interpreter himself" (Borisov, 2006, p. 361). In our case, we applied Betti's idea of the influence of the object of interpretation over the subjectivity of the interpreter himself to studying the influence of a work of art on the viewer's subjective life, in particular, on the strengthening and/or expansion of the viewer's identity.

The position of Hans-Georg Gadamer, according to which understanding is not the result of interpretation as a subjective activity, but an event that only makes subjectivity itself possible (2006), is significant for us. In accordance with such a methodological approach, we consider the problem of the functioning and transformation of the spectator's identity as encounters with objects of art that are constituted and transformed by the event. The specific aspects of the spectator's identity are studied in our work with the help of Gadamer's theory of application. According to Gadamer, the application of text has a meditative character, directly affecting the subjectivity of the interpreter. The historical part of our study was informed by Gadamer's idea that understanding is always more than mere reconstruction, but is rather fundamentally ambiguous and non-final, changing according to socio-cultural context.

One of the accents of our researching is the study of the characteristics of the media environment, communications that arise in the process of musical and dramatic works perceiving. It seems important to us to turn to the ideas of the philosophical hermeneutics of H.-G. Gadamer in understanding of this experience. Gadamer wrote about three types of hermeneutic experience by analogy with three types of human communication. The first type of communication does not actually imply a genuine dialogue. "There is a kind of experience of the Thou that tries to discover typical behavior in one's fellowmen and can make predictions about others on the basis of experience" (Gadamer, 2006, p. 352). According to this attitude we see in the Other only a tool that lends itself to accounting and mastery. Gadamer evaluates this position in relation to "Thou" as the purest egoism and condemns it referring to the categorical imperative of I. Kant. Gadamer describes the second type of experience of the relationship to "Thou" as a reflexive form of striving for domination, when a communication partner "claims to know the other's claim from his point of view and even to understand the other better than the other understands him" (2006, p. 353). This position makes a genuine dialogue impossible, since we take ourselves out of mutual connection and make ourselves inaccessible for communication partners with such claims. According to Gadamer's hermeneutics the third, highest type of hermeneutic experience which he calls the activehistorical consciousness, corresponds to human communication. This communication is an experience of "Thou" and is characterized as a fundamental openness 
to each other which forms the basis of genuine human ties and connections. According to Gadamer the meaning of the text is reborn each time in a dialogue with the recipient, that is, the meaning of the text does not exist outside of interpretation. "We understand in a different way, if we understand at all" (2006, p. 296), Gadamer said. The interpretation of the object of art appears as an existential event in human life, as a form of self-reflection.

In our understanding of the nature of the funny and the comic, we rely on the relational theory of the comic, as presented in the classical works of Jean Paul and Henri Bergson (2005). According to this theory, comic nature is found neither in the object, nor in the subject of funny practices, but in the relationship between them. Mikhail Bakhtin's theory of carnival culture (1968) revealed elements of carnivalism in various historical types of theatrical practices. In the analysis of contemporary musical and dramatic art, the semantic theory of verbal humour put forward by Victor Raskin (1984) and Salvatore Attardo (2001) was productive for us. The key idea of this theory is that the comic arises as a result of the inexpediency, incompatibility and contraposition of scripts, i.e. alternative readings of the text.

Our analysis of absurd artistic practices was based on Albert Camus' philosophy of the absurd, in particular on his aesthetic position of ironic detachment being essential for survival in an absurd world. Intense and shocking interaction with the viewer was seen as a central feature of contemporary art in Antonin Artaud's concept of the "theatre of cruelty", and this serves as the basis for our interpretations of provocative practices in musical theatre.

We will understand spectator identity as the identity that is formed in the interaction of the viewer with works of art. At the same time, we will understand the process of spectator perception of art objects as an intermediary between the spectator's subjectivity and the performance. The methodological basis for this position is the narrative identity theory of Paul Ricœur (1992), according to which a character's identity is generated by a narrative, which in our case is created by the communication between the viewer and the artwork. We share Ricœur's idea that the identity of the narrative is related to the temporal dimension of the Self, and should be seen as a dynamic process.

\section{The transformation of spectator receptions: a historical perspective}

Contemporary trends in art appeal to the removal of the binary, which changes the ontology of art objects, while catharsis ceases to be unambiguously tragic or comic - the strict standardisation of artistic forms and techniques disappears. This impacts not only works of art themselves (in our case, the performance), but also their reception. It should be noted that the change in the viewer's perception of the object of art is a feature not only of the modern age, but is also characteristic for all historical stages of artistic practice. 
The normality of artistic reception has never been constant, approved once and for evermore. For example, in the era of Elizabethan theatre in England, Shakespeare's contemporaries perceived the performance of "Hamlet" as an actionthriller, based on detective investigation with elements of horror. This interpretation was quite in line with the spectators' horizon of expectations, and it defined and confirmed the personal and collective identity of the theatre-going public. A metamorphosis occurred during the Enlightenment: a transfer of meanings took place in accordance with new worldviews, and the same play came to be considered as an intellectual drama. Its main pathos was now signified by the tragic conflict between the reflexive hero and existential circumstances, which for a long time determined the intention of the interpretation of both the play and its performances, as well as the expectations of the audience.

But Shakespeare's productions were never devoid of comic elements, whether the performance was perceived as a work of horror, or in the enlightened pathos of seriousness. This was due to the traditions emanating from the specific features of Elizabethan theatre, in particular the demand for the presence of both tragic and comic elements within the dramatic text. The difference between them was already formally expressed in the manner of the writing: Shakespeare's comic elements were written in prosaic, vulgar language, while the tragic elements were expressed in verse: the lingua vulgaris was used in Shakespeare's plays to balance the tragic and comic elements. At the same time, the comic and tragic were formally clearly separated from each other by language markers. This gave the audience clearly defined guidelines on how to perceive and react to the play, allowing the audience to retain a strong identity. Functionally, this textual separation is isomorphic to the modern reception of scene-setting laughter, prompting the appropriate reaction in the viewer.

The trends noted above were also characteristic of Baroque theatre, with certain variations, and in this case, audience identity was aligned according to class divisions. For example, in Venice at the end of the 17th and in the first half of the 18th centuries, there were many musical theatres which were ranked by class: members of the upper classes had their own theatres, and would consider it unacceptable to patronise theatres which catered for the lower classes. That is, the audience's identity was linked to their social status, and in so being, part of their social identity. The performances themselves and the behaviour of the audience were akin to carnival culture.This was expressed in the behaviour of the audience by the absence of any taboo over open demonstrations of base human urges, as well as the acceptability of an ecstatic, at times vulgar, reaction to what was happening on the stage, that is to say, the normality of decency was replaced by the inverted normality of the carnival. The comic components in such plays were manifested through changing clothes and gender roles, travesty, the use of unexpected plot twists and plot schemes, and by mixing expectations and positions. Satire was aimed at mocking the perceptions and stereotypes inherent to the social and cultural identity of the time. 
The comic elements sometimes performed the function of outrage, bringing the public out of their state of stable habitual identity. In the famous baroque "Le ballet de la Merlaison", the author - Louis XIII, King of France - appeared on the stage, unexpectedly for the court audience, in the travesty role of a comic old woman selling bird-bait. This discrepancy between the dancer's high social status and the image he embodied led the audience beyond the usual limits of aesthetic, ethical and ceremonial norms.

The normative seriousness of the theatre during the epoch of absolutism also determined the level of acceptability of comic elements as well as its boundaries. The theatre was a matter of state importance, and it was required to reflect, directly and unambiguously, the weight and significance of monarchic institutions. Comicality was allowed on the stage only as a necessary element in the balance of interaction between different components of the art world, and then only to reinforce the status of the seriousness. According to classicist aesthetics, rigid limits and frameworks were imposed on the acceptability of the comic. The independent role of the comic was to a large degree negated by the extent of the aesthetic, which was aimed at the formation of good manners and the ostentatious expression of sublime ideals. However, in spite of this emphasis on seriousness, court theatre was still unable to avoid comic elements altogether. They were used as a necessary "spice", and a kind of vignette to decorate the seriousness. As a rule, the participation of crowned persons and representatives of high aristocracy in performances was decorated by comic plot twists and jokes over their surroundings, which only added to the glorification of the central characters and the high persons playing their roles. All of the above helped to achieve the main goal - the exaltation of the monarchy - and it was in accordance with this goal that the boundaries of acceptability for satire were drawn up. Even in comedy plays, satire was strictly regulated.

\section{Musical language and comic semantics}

In accordance with the principles of classical aesthetics, the most frequently performed works skillfully combined elements of high and low genres, the comic being associated with lower culture, and the heroic with the higher. This was expressed not only in the plot, but also in the musical material of the works. In Claudio Giovanni Antonio Monteverdi's opera "Lincoronazione di Poppea", the nobility of the positive characters is thrown into sharp relief by the bustle and vulgarity in the musical material of the part of Arnalta, the nurse. The comic qualities of this travesty role were enhanced by both the text and the music: the role of the nurse was intended for a comic tenor.

The status of positive characters is expressed using normative aesthetic rules and principles. Musically, this manifests itself in the harmony of consonances, the correct construction of musical phrases, its rhythmic pattern. The status of comic characters is musically articulated by overinflated sonic imitations of vulgar 
physiological processes, such as the famous aria of Cold Genius in Henry Purcell's semi-opera "King Arthur", where the state of a shivering man is comically played out.

The ability of music to express various nuances of the comic was developed in the works of Wolfgang Amadeus Mozart. That which is funny is always associated with the confounding of expectations, something to which Immanuel Kant also paid attention in his own definition of laughter (2000, p. 209). In Mozart's early work, an interest in imaginary playing, identity juggling, substitution and pranks can be observed. Through the medium of music, Mozart expresses the comic not only as something which is simply in opposition to the serious and deserving of derision, but also introduces comicality into a wider semantic field, connected with the play of identities, illusion, imagination, imaginative state and me-thinking (Levchenko, 2017, pp. 176-177).

In Mozart's later work, this blurring of genre boundaries will become a frequently used technique, one that creates ample opportunity for a game of identities by the main and secondary characters, as well as for a kind of "juggling" with meanings of personal metamorphoses, experiences and disguises. In this way, the comic scene, when placed in a lyrical context, lifts the funny from the level of mere amusement to the level of the sentimental and the sublime.

In opera, comic content was traditionally provided by the libretto. Mozart, on the other hand, was a proponent of the priority of music over the dramatic text. In this regard, he highly rated the Italian comic operas of his time. In one of his letters to his father, he noted as follows:

"Why do Italian comic operas please everywhere - in spite of their miserable libretti - even in Paris, where I myself witnessed their success? Just because there the music reigns supreme and when one listens to it all else is forgotten. ...the words written solely for the music and not shoved in here and there to suit some miserable rhyme..." (1938, p. 1150).

That is, the comic, in Mozart's mind, is for the most part provided by musical means rather than by the literary component. In all his operas, Mozart demonstrates this ability of the musical language to express the subtlest nuances of the comic and the funny. For example, in the vocal duel between Susanna and Marcelina in "Le Nozze di Figaro", the comic character of this battle is masterfully conveyed through parodies and repetitions of musical lines.

What was characteristic of Mozart's late operatic work was that he was not concerned with the then prevalent satirical orientation of the literary source of the libretto, but rather, through music, he moved semiotically towards revealing the diversity of meanings. For Mozart, the main thing was to access a more universal level through the comic and the funny. His attitude to the libretto was determined by the possibilities for the musical manifestation of the characters and their relationships. "Each manner corresponds to its own music. It expresses not only a variety of intonations of desire, but the whole range of passions: next to the many varieties of love is a place for fun, melancholy, greed, fear, anger, vanity, 
remorse, forgiveness, etc." (Starobinsky, 2002, p. 469). Mozart uses different expressive means - rhythmic, tonal shades, etc. - to express his heroes' characters, experiences, passions and feelings, both comical and lyrical. All of them, in their diversity, recreate an organism borne of the mutual influence of instrumental and vocal components, and the ironic removal of outdated operatic hallmarks creates the effect of encountering an extraordinary aesthetic integrity. The answer to the question "what is a human being" is achieved in this integrity of diversity. Thus, even the character of the man-bird Papageno, the trickster from "The Magic Flute", shows us that the imperfection of human nature is itself also human.

\section{The transformation of the comic and humanistic ideal in the musical theatre of the 19th and 20th centuries}

The universalization of the funny, and the consideration of the comic as the means to express the humanistic ideal was further developed in 19th century musical theatre. The democratization of European social life blurred the classicist aesthetic ideal, and the rigid demarcation of comic genres and the theatrical ways of presenting that which elicited laughter was overcome. The previous divisions into court comedy, town square comedy, the comedy of masks, etc. were mixed together. Moreover, comedy itself changed its status: having shaken off its tinge of the second-rate, it ceased to be perceived as entertainment mainly for the lower strata. This made comedy one of the most popular genres in both dramatic and musical theatre.

During this period, comic opera underwent an incredible flourishing. Especially revealing in this respect are the works of the brilliant Italian composer Gioachino Antonio Rossini. In his operas, the comic acts as a force capable of removing the cloak of imagery from reality, passing through a series of initiations which allow the characters to realize their destiny. In "The Barber of Seville", the aristocrat Almaviva must pass through a series of unusual "initiations" to achieve his desired goal of being united with his beloved. He must appear either as a drunk soldier or as a machinator - a music teacher, or an eternal student. The comedy of these transformations is expressed both musically and scenically.

It is the comic that Rossini uses as a touchstone (incidentally, touchstone is the English translation of the title of one of his popular opera buffas, "La pietra del paragone") to reveal the imaginary and to expose the inauthentic. Whereas in the previous classicist aesthetics the comic was understood as being identical to covetousness, falsehood and inauthenticity, in Rossini's operas the comic was more a way of overcoming the imaginary, of revealing the authenticity of relationships. For example, in the opera "Cinderella" ("Cenerentola") it is the vortex of comic images and characters which swirl in an unbroken sequence and alternation of non-recognition and recognition, social roles, changing clothes, modes of behaviour and speech expression, which enables the exposure of the false and the untrue, and attains the level of authenticity and truth. 
A novelty for musical theatre was Rossini's comic treatment of solemn and topical subjects, as shown in the opera "Il Viaggio a Reims", dedicated to the celebrations surrounding the coronation of King Charles $\mathrm{X}$ of France. Previously, such events had been marked by coronation masses, anthems, odes, and operasseria, such as "La Clemenza di Tito", written by Mozart for the coronation of Emperor Leopold II, but never by comedy performances.

For all the innovations, "spectator-actor" interaction in the traditional model of theatrical art was strictly regulated. The stage's "fourth wall" clearly demarcated the addressant and the addressee: actor and spectator. By default, the spectator was assigned the role of the passive object of perception and the experience of theatrical action (through catharsis). Unlike the modern theatrical model, the spectator was not to interfere with what was happening on the stage. Whereas in modern theatre spectator activity is not only allowed but also welcomed, in traditional theatre it was sanctioned and perceived as worthy of anecdotal status. For example, this remarkable story, which took place with enviable regularity in the Odessa city theatre, entered into the annals of urban folklore. According to local Odessa legend, in the first half of the 19th century the refined theatrical public was so sensitive and knowledgeable about musical material that the emotional excitement would increase as a culminating aria approached, and the anticipation of ecstasy galvanized the atmosphere in the theatre. One of the greatest and most competent opera-goers at that time was the head of the Odessa police, who did not miss a single performance. For him, aesthetic order was identical to social order. However, to the horror of the official, each time when the culmination began on the stage, a tired human meowing could be heard from the depths of the hall. In this way, one local joker, in shocking violation of all norms of audience behaviour, drove the policeman into a frenzy, and the ladies to a-swooning. The solution to this comical situation was no less comical. The head of the police assigned two subordinates to this aesthetic hooligan, with orders to summarily expel him from the hall on the go-ahead of the chief when he sensed the approach of the opera's climactic aria.

At the beginning of the 20th century, the understanding of the essence and the functions of the comic, and its relationship to seriousness in the theatre, changed fundamentally. This process was isomorphic to a change in attitudes towards understanding the essence of art and the human being. Art turned away from its exclusively mimetic nature, and from the rigid unidirectional relationship between the recipient and the work. The social theory of art ensures its appeal to wide spectator-participation, and accents in the field of the comic move towards social satire, of which in opera the most striking examples were the zong operas of Kurt Weill and Bertolt Brecht "Die Dreigroschenoper" ("The Threepenny Opera") and "Aufstieg und Fall der Stadt Mahagonny".

In the worldview of the 20th century, the previously definite relationship between seriousness and comicality was turned on its head. "The Cherry Orchard"'s burden of existential problems and the play's tragic overtones no longer prevented 
Anton Chekhov from describing it as a comedy. In late modernistic art, the tragic and the comic begin to act as twins. The comic is aimed at seriousness, without which the latter is impossible. The ultimate conjugation of the tragic and the comic was adequately expressed in the musical theatre of the time. Some of Igor Stravinsky's ballets and operas are indicative in this respect: the musical centre of the ballet "Petrushka" is the tragic despair of the comic character. The composer skillfully intertwines the images of a folk booth with all its comic elements with the classical seriousness of academic melos, all the while parodying the traditional genres of musical theatre. In his late opera "The Rake's Progress", written in William Hogarth's satirical series, Stravinsky closely intertwines the horrors of personal and social madness with a satirical display of the main character's circumstances. The means to involve the audience as interpreter of the famous plot is the use of quotations and the creation of remakes based on the themes of famous classical operatic works.

The satirical component was used to criticize quite serious artistic declarations. The intellectual battles of the avant-gardists, literary and theatrical manifestations, and traditional positions on the hierarchies of genres are played out ironically in Sergei Prokofiev's opera "The Love for Three Oranges". The composer uses various musical means with precision and wit. The artistic world of the 18th century comedies which he revives brings the spectator into a space of universal senses and images, amazingly without losing the connection to topical contemporary themes.

\section{The absurdity and optics of the comic in contemporary musical performance}

The mutual intertwining of the tragic and the comic in art expresses a global outlook on the perception of the world in new optics as a kind of comically tragic or tragically comic. The absurdity of life is now interpreted as an undeniable ontological fact. Accordingly, in the 20th century artistic practices based on the idea of absurdity as their own regulator become more widespread. Absurdist artistic practices were based on philosophy of absurdity vividly represented in the writings of the existentialists, particularly Albert Camus. In his works devoted to absurd thematics, the French philosopher applies an aesthetic criterion. According to Camus, the absurdity of existence can be compensated for by the beauty that makes life worthy of continuation. Camus identified the aesthetic position of ironic detachment as essential for survival in an absurd world (Camus, 1955).

New artistic practices rejected the aesthetic canons of rationalism and the means of universal logic, exposed the inner workings of meaning, and revealed the absurd aspects of human existence through laughter. In his book "Theater and its Double", one of the founders of the so-called "theatre of cruelty" Antonin Artaud formulated the basic laws of the new dramatic art. The playwright excoriated the entertainment-oriented "digestive" theatre, calling for it to face up to the harsh realities of life and to abandon its humanistic and psychological orientation. 
According to Artaud, events taking place on the stage are based on memories; memories to which the spectator is also connected through the collective unconscious, thus becoming an accomplice to the performance (Artaud, 1994). Since living memory by definition includes distance, the ironic detachment of Camus' position is inevitably implied.

Throughout the 20th century, absurd ideas were in great demand, and found themselves manifested in a variety of ways in the practice of musical theatre.

At the end of the 1920s, such ideas were used extensively in avant-garde musical practice. For example, in the opera "The Nose" by Dmitry Shostakovich, the absurd message of the literary source material gives rise to an altogether new interpretation, in which Gogol's impossible fantasy plot is turned by Shostakovich into one that is real and topical. "The Nose" becomes a biting satirical performance depicting the absurdity of modern life, and this transformation is accomplished through new musical means and forms. The composer mixes diverse musical styles, techniques and materials: balalaika-accompanied singing with atonal fragments, gallops with fugues, a classical orchestra with folk instruments. The eccentric elements of the opera take on a grotesque character. In his experiments with the vocal parts, the composer went beyond normal vocal registers: numerous actors on stage coughed, squealed, sobbed and sneezed. The fussiness and absurdity of what was happening was emphasized by the constant, almost cinematic change of visuals and musical intermissions. Gogol's original problem of Major Kovalev searching for his identity is transformed into a means of undermining the very identity of the stunned spectators.

Absurd motifs that provoke and challenge the audience accompany musical theatre throughout the course of the 20th century. The spectator is given new optics through which to perceive the performance, forcing him or her to participate, to become involved in an exciting quest, and calling into question not only the system of well-established dispositions, but also the very idea of the stability of the Self. Etymologically speaking, the word "absurdity" is connected with deafness (ad absurdum), the inability to perceive sense, and in this respect it borders cheek-by-jowl with nonsense. The absurd is thus capable of providing a transgressive transition from the intolerable emptiness of nonsense to the acquisition of new meanings.

The exaggerated absurdity of onstage events leading the audience out of their comfort zone is the core technique of Alfred Schnittke's opera "Life with an Idiot". By means of the grotesque, Schnittke and Viktor Erofeev, the author of the libretto, provoke the audience with the rudeness and cruelty of what is happening on stage, shock spectators and transfer them from the position of distant observation into the position of anxiety and searching their own inner conflicts, seeking the idiot within themselves rather than among the characters of the performance.

"In vocal and intonation terms, the composer mainly uses sharp, broken irregular melody - tritone intervals, seconds and septima, actually forming a separate semantically significant group, the purpose of which in the opera is to complicate 
and aggravate the plot action with its sharp, unstable sound" (Samokhvalova, 2011). The destruction of familiar moral and aesthetic standards for the audience compels them to seek new explanation schemes, changing their ideas both about their own identity and the normativity of art.

The melding of acutely grotesque, satirical and absurdistic expressive means is perceived as a universal artistic norm in the culture of the 20th century. All of this abruptly changes the content and hierarchical status of the classical aesthetic categories: the ugly replaces the beautiful, the sublime merges with the base, the tragic dissolves into the comic, the ridiculous reveals the soft underside of the serious.

Such semantic transformations are inevitably accompanied by the destruction of the classical musical canons. The opera "Le Grand Macabre" by the famous Hungarian composer György Ligeti, based on the drama "La Balade du Grand Macabre" by the Belgian avant-garde playwright Michel de Ghelderode, is indicative in this sense. Ligeti's work is constructed as an antithesis to social and musical dogmatism. "The opera tauntingly ridicules the political systems that terrorized Ligeti throughout his life: the main character (antihero) has the name Nekrozotar or Grand Macabre, and has the features of totalitarian dictators of the 20th century obsessed with death" (Kan, 2017).

The freedom and fun of fairytale Bregelland is opposed by the deadly and horrifyingly serious Nekrozotar, for whom fun, joy and freedom are the main threats to his power, and only the merriment of the carnival saves this country from destruction. In the music of the opera, both the traditional opera clichés of the classics of the genre (Mozart, Rossini, Verdi and Offenbach) and the rationalistically serious statements of its avant-garde contemporaries (Stockhausen and Boulez) are ironically played out. The composer uses unusual and shocking musical techniques: at the start of the opera, for example, a cacophonic chorus of a multitude of car horns rings out. In the interpretation of contemporary American director Peter Sellars, the funny - the musical hooliganism of Ligety, filled with the shocking profanity and sophisticated wit of the libretto - reveals the apocalyptic flip side of the modern post-industrial world, and sounds as a warning of possible nuclear disaster.

\section{Artistic provocation as deconstruction of the "serious - funny" binarity}

With the death of the postmodern, the architectonics of aesthetic questioning itself underwent a transformation. At its heart now there was the question of the boundaries of art, and often a more radical statement about the lack of art itself as a specific activity in engendering artistic meanings. By way of example, let us recall Mikhail Yampolsky's provocative assertion that there is no such thing as art, only anthropological practices (2015). In Yampolsky's opinion, art arises when its description emerges, and narrative is a form of its legitimization. 
"...it [art-V. L., N. K.] is created by description... because art exists not only as a result of individual creativity. In order for something to find its way into the spectator's attention, it must be institutionalized through the opinion of experts, curators, through institutions that agree to exhibit it. ...A spectator is not something autonomous. The spectator is apart of the institutional functioning of what we call art. He is obliged to come to an exhibition because he has read about it, because he is told that there are important and interesting artists" (Yampolsky, 2015).

Pierre Bourdieu includes into the space occupied by art not the actual content of works of art, but rather the social conditions that have an impact on their form and content. According to Bourdieu's theory, aesthetic preferences are the marker that allows us to make a distinction between social groups and their life styles. In his research into the factors affecting the creation of artistic works, Bourdieu points out that the decisive role in this process is not so much the author's activity, but the resulting action of an ensemble of actors in the artistic field (champs). That is to say, artistic production includes not only the creation of an artifact, but also an entire system of commentary which marks the work as valuable and relevant to the audience.

\begin{abstract}
"The producer of the value of a book or a painting is not the author, but the field of production which, as a universal belief, produces the value of a work of art as fetish, producing faith in the creative power of the author. A work of art exists as a symbolic object representing the value only when it is recognized and accepted, i.e. socially institutionalized as a work of art by readers or spectators who have the disposition and aesthetic competence necessary to recognize and accept it as such" (Bourdieu, 1991).
\end{abstract}

In this way, contemporary aesthetics argues that art cannot exist without a discourse which interprets it. "If there is no expert who tells you that it is a work of art because it fits into the tradition one way or another, then we do not know whether Duchamp's urinal is a work of art or not" (Yampolsky, 2015).

However, this position was questioned in the aesthetic explorations of the second half of the 20th century. The right of art to produce effects only if it is legitimized by the actors of the art process is criticized by the American art theorist Susan Sontag in her essay "Against Interpretation".

"To interpret is to impoverish, to deplete the world - in order to set up a shadow world of "meanings." It is to turn the world into this world. ("This world"! As if there were any other.)" (Sontag, 2013, p. 4),

she notes sarcastically. According to Sontag, interpretation is a reactionary, cowardly and suffocating activity directed against art itself and the a priori imposition of predetermined meanings to a work of art simultaneously legitimizes and castrates its aesthetic effect, thereby shutting off the possibility of properly seeing the work in its own right. However, in order to move away from interpretative determinants, it is necessary to create "works of art whose surface is so unified and clean, whose momentum is so rapid, whose address is so direct that the work can be... just what it is" (2013, p. 7). This premonition of the fate of art by Sontag, which 
was not relevant to the state of artistic practice of its own time, is being actively realised today (Serkova, 2019). For it is today that we encounter in artistic activity the liberation of objects of art from the pretension and necessity of schemes according to their preliminary interpretation, and this raises both the question of the necessity to construct new receptive models for experiencing objects of art, and the question of what the content and basic foundations of this model are.

In answering these questions, Sontag concludes her essay with the following thesis: "In place of a hermeneutics we need an erotics of art" (Sontag, 2013, p. 10). According to Sontag, an object of art is by its very formal presentation so self-sufficient and complete that not only is interpretative propriety superfluous, but it also obscures the ability of the work of art to directly bestow the fullness and multitude of its meanings. The effect of meeting with the object of art itself, not placed within a framework of foreseeable interpretations, becomes a shocking event for the viewer, one which provokes both an attractive captivation and the urge to flee from this encounter with "naked art".

In considering the peculiarities of contemporary art's existence, and its reception as the dominant aspects of artistic endeavour, the Russian scholar Natalia Serkova notes that modern art is characterized by "the observance of at least two conditions - our refusal to fence ourselves in with knowingly false and incomplete interpretations, and the intense, shocking interaction between ourselves and the object". This gives the spectator "a chance to shift and expand our understanding of reality" (Serkova, 2019).

The expressive means used as to solve these problems is provocation.

One trend in contemporary opera and ballet direction is the bringing up to date of story lines, the transfer of action into the realities of contemporary culture, which are called upon to shock the spectator. For example, at the Salzburg Festival in 2008, Klaus Guth and Brian Large staged Mozart's "Don Giovanni" with all the events unfolding on a garbage dump, and where Don Giovanni, Donna Anna and the other aristocratic characters were homeless people. Under such directorial decisions, the action of the characters is in emphatic dissonance with the traditional text of the libretto coming from the stage. Such an intentional collision of the aural and visual sequences pushes the "traditional" viewer out of their usual conservative and academic expectations, giving rise of new meanings. The main aim of such provocations is to draw the spectator into a state of complete uncertainty and aesthetic shock. The spectator turns out to be similar to the participant in the Socratic conversation described in Plato's "Menon". Socrates' interlocutor, drawn into a stupor by his questions, complains that he feels as if he has been stung by a stingray. For Plato's Socrates, this is probably the only possible way to know the truth and, consequently, to know oneself. Susan Sontag, discussing the eroticism of art, re-creates the same model: the object of art must appear directly before the beholder, devoid of any interpretative clothing. This "nakedness" leads the viewer into a stupor whereby he, "stung by a stingray", can neither look at the object of art nor avert his eyes from it. But it is exactly this kind of stupor 
which inevitably leads a person to engage with the object of art, and gives them the possibility to gain a new understanding of oneself.

This state of aesthetic shock is, as we see it, presented on the border of the funny and the serious. Provocation acts as a transgression, i.e., overcoming borders and deconstructing classical binary oppositions: high - low, spiritual corporeal, serious - funny. According to its own conception, transgression is a concept that fixes the phenomenon of crossing an impassable boundary, and above all the boundary between the possible and the impossible: "transgression is a gesture that faces to limits" (Foucault), "overcoming an insurmountable limit" (Blanchot). According to this concept, "the world is a given, delineating a sphere of the possible known to a human being, enclosing him within its borders, cutting off any prospect of novelty for him. In this context, transgression is an impossible (if we remain in this given system of reference) way out of its limits, a breakthrough for those who belong to a reality outside it" (Gritsanov, 2001, p. 842).

The art of contemporary music and drama functions in this mode. For example, in the Mariinsky Theatre production of the opera "Life for the Tsar" by M.I. Glinka, the tragic circumstances of Ivan Susanin's death at the hands of the Polish occupiers are explained by intentionally banal and topical everyday reasons: there is no mobile phone coverage area in the forest into which he led the Poles. This directorial decision comes into conflict with the audience's expectations, sets the scene for an ironic reading of the famous narrative, and destroys the heroic pathos of the original musical source.

The strictness of the binary opposition "serious - funny" is subjected to deconstruction in the performances of the famous dance theatre of Pina Bausch. Her productions, created at the boundaries of drama, performance and choreography, are provocative in nature. The audience at these performances is deprived of its usual aesthetic expectations, "an illusion of the identity, falling into the field of surprise and existential uncertainty" (Kovalova, 2013). In the majority of the productions there is no plot, no main and no secondary characters. The ballet dancers defile in dresses and heels, and they look like ordinary women, sometimes with figures that are far from the ideal. The actors in Bausch's productions doll themselves up, dress up, chatter about everything and nothing - they, like all other people, create the Erzatz of themselves, i.e. the perceptions of themselves as demanded by culture. The actors provoke the audience, addressing it with unexpected questions that drive it out of the usual and comfortable state. The actors are not against "invading the space immediately close to the observer, which he had previously considered completely decoded and safe" (Serkova, 2019). The positions typical for the traditional theatre, on the one hand, the spectator's contemplation and, on the other, the actor as the object of the audience's gaze are overturned and replaced by new immersive communication methods (Kovalova \& Levchenko, 2016), - for example, by active tactile relations between the actors (as initiators) and the baffled spectators. The actor can not only approach the spectators, but, for example, hug them, stroke them, even sit on their lap. The act of touching is 
a trigger that shatters the spectators' stable identity and provokes them to destroy the ideal notion of their own self-determinism. Bausch's performances reveal an emotional world of the unconscious through sensual, bodily, everyday experience. The body in the concept of her dance theatre is not understood as passive and meaningless and is not opposed to the spiritual as active and meaningful. The corporeality in the Pina Bausch model of dance overcomes the Cartesian dichotomy of "soul - body", revealing itself as a product of social interactions, a type of sensuality inextricably linked with a certain type of thinking.

Playing has become a basic phenomenon of postmodern culture, including playing with tradition. If modernism struggled with it, then postmodernism simply ignores it, moving away from the totalitarian possibility of the domination of a single cultural (including artistic) norm. As Umberto Eco accurately noted, such play always contains an ironic component, because the past is indestructible, it must be ironically rethought without naivety (Eco, 1984). In the same way a contemporary musical performance goes from the semiotic space of the original genre to the field of oscillating meanings and signs, unstable, open, containing and assuming many interpretations including irony.

The ironic play characteristic of contemporary art is primarily directed towards itself, and acts as a self-irony. For example, in the mini-mono opera "Boris Godunov Tonight" (2008) by the Odessan composer Karmella Tsepkolenko, all the action takes place behind the scenes. The hero, an opera singer preparing to take to the stage in the role of Boris Godunov, reflects on the historical fate of his character, building an analogy between him and his own personal destiny. Let us highlight two moments of the play. First, there is ironic treatment of the traditional mimetic model whereby artistic reality reflects empirical reality. In the opera, on the contrary, artistic reality itself determines empirical reality: the role the actor is playing sets possible lines for his destiny. The actor, considering for himself the destinies of the main characters - Godunov, the Pretender, Shuisky, the Yurodivyy (The Holy Fool) - rejects such a game of identities and refuses to take part in the event. The ironic effect is doubled by the overcoming of the traditional actor - character dichotomy, playing them in intertwined, anecdotal entanglement, where the actor tries on the identity of the character, and the character takes over the identity of the actor.

Secondly, this play shatters the romantic pathos of the primacy of artistic reality over the empirical. The confidence of the actor that his fate can repeat the fate of the character is ironically deflated. The same irony can be traced in the musical text: the musical content of the mini-monopera is skillfully woven together by referencing the original musical text of Mussorgsky with parodical intent.

In contemporary art, classical forms and ways of presenting "high art" as sublime is exposed to parodic ridicule. In contemporary theatre, as well as in other kinds of art there are no taboos whatsoever. In contemporary ballet productions, the "profanation" of classical ballet in all its manifestations (technique, 
style, etc.) takes place in a variety of ways. For example, in the ballet "Swan Lake" by the choreographer Matthew Bourne, Shakespeare's "performance within a performance" is used to ridicule the claims of romantic ballet to indisputably top status. The destruction of gender expectations in the ballet is used as a powerful tool for this parody: the traditional roles of swans in the ballet are performed by men. Moreover, it is not the performance of traditional female roles by men that turns out to be funny (it rather brings tragic motifs into the drama); it is the traditional, gender-"normal" schemes of romantic choreography which look ridiculous.

The self-parody in the ballet "Alice in Wonderland" (Covent Garden Royal Ballet, 2011) is achieved using exclusively choreographic means. Choreographer Christopher Wheeldon ironically quotes famous choreographic scenes, toughening plasticity, violating classical proportions, distorting the drawing of normative ballet poses. For example, the dance of the Queen of Hearts with four knaves refers to the famous Aurora dance with four gentlemen from Marius Petipa's "Sleeping Beauty".

In this way, provocation in contemporary musical theatre acts as a mechanism for shattering established forms of cultural normativity, releasing meanings that are outside of the existing symbolic field, and creating conditions for the transgressive transition between the possible and the impossible.

\section{Conclusions}

Our analysis of the history of musical and dramatic theatre - at least of the Modern era - demonstrates the sustained presence of comic elements within the genre. In the theatre of the 16th-17th centuries, the comedic took the form of caricature, a satirical mockery of traditional cultural norms, the serious and the funny were rigidly separated, and the art was rather a means of constructing and maintaining the audience's group identity. However, by the time of Baroque theatre elements of the shocking already began to emerge, shattering the stable audience identity and expressing topoi that lay beyond normative cultural representations. A transformation of the comic took place in classicist aesthetics: it became rather a means of shading serious themes, with the application of comic elements strictly regulated, tabooed, - in particular the application of the comic to power. That which is comic was understood as being equivalent to covetousness, falsehood, and inauthenticity.

In the 19th century, the status of the comic changes, and it begins to denote a force that removes the shroud of imagery from reality. Particularly in the operas of Rossini, the comic appears rather as a way of overcoming the imagination and exposing the inauthentic, a way of reaching the authenticity of relationships.

For all the differences in the understanding of the nature of the comic throughout the Modern era right up to the beginning of the avant-garde searches of the 20th century, the same certainty of the comic endures, i.e., the clear labelling of the comic as comic. The communicative axis of "performance - spectator" 
was strictly defined, giving a clear and unambiguous interpretational vector to the spectator, thus supporting the collective audience identity. The theatrical avant-garde changes this situation: the "fourth wall" collapses, "performance spectator" communication becomes horizontal, thus transforming the spectator into an equal participant in the production of meanings. This new format of spectator involvement implies the use of provocation as a necessary pre-condition in order to take the viewer out of their stable state of tranquility and certainty, and to draw them into a state of creative activity. The performance becomes an attraction to immerse the spectator in shock undermining one's own identity.

At the same time, in modern culture laughter acts as a shadow mechanism providing the shortest path to a philosophical understanding of serious problems, the articulation of which is impossible without the comic element.

Various types of the comic, such as humour, irony, sarcasm, and (self) parody, are now transformed to fit into the stylistics of the absurd, deconstructing the boundary between the funny and the serious, and provocation is a means which facilitates these processes. All of this inevitably leads the spectator to new interpretations of the object of art, and creates the possibility of constructing a new (self) narrative.

Such provocation acts as a transgression, i.e., it overcomes boundaries, changes the relationship between the actor and the spectator, the serious and the funny, empirical reality and artistic reality.

The original understanding of the comic and the funny has always been distortion, overturning, breaking up the established and the familiar. It is these very characteristics of the comic that are effectively used by contemporary art, making provocation its effective and integral element. The funny in this situation loses both its stable certainty and the clarity of its boundaries, seeping into all pores of culture.

\section{References}

Artaud, A. (1994). The Theater and Its Double. New York: Grove Press.

Attardo, S. (2001). Humorous Texts: A Semantic and Pragmatic Analysis. New York: Mouton de Gruyter.

Bakhtin, M. (1968). Rabelais and His World Cambridge (I. Iswolsky, Trans.). Bloomington: Indiana University Press.

Bergson, A. (2005). Laughter, an essay on the meaning of the comic. London: Dover Publications.

Betti, E. (2017). Chapter 7: Interpretation of Drama \& Music. In General Theory of Interpretation. London: Createspace Independent Publishing Platform.

Borisov, E. (2006). Preface to the publication of "Hermeneutics as a General Methodology of the Humanities" by E. Betty. In $\triangle o ́ \xi \alpha$ / Doxa. Collected Scientific Articles on the Philosophy and the Philology: Vol. 10: Strategies of the text interpretation: methods and borders of their using (pp. 361-367). Odessa: Odessa National University named after I. I. Mechnikov. (In Russian).

Bourdieu, P. (1991). Le champ littéraire [Literary field]. Actes de la Recherche en Sciences Sociales, 89(1), 3-46. doi: 10.3406/arss.1991.2986 (In French). 
Camus, A. (1955). The Myth of Sisyphus and Other Essays (J. O'Brien, Trans.). Retrieved from https://postarchive.files.wordpress.com/2015/03/myth-of-sisyphus-and-other-essays-thealbert-camus.pdf

Eco, U. (1984). Postscript to The name of the rose. San Diego, New York and London: Harcourt Brace Jovanovich.

Gadamer, H.-G. (2006). Truth and Method. London and New York: Sheed \& Ward Ltd and the Continuum Publishing Group.

Gritsanov, A. (2001). Transgression. In Postmodernism. Encyclopedia (p. 842). Minsk: Interpressersvis; Knizhnyiy Dom. (In Russian).

Kan, A. (2017). Le Grand Macabre - Opera for Trump era. BBC News Russian Service. Retrieved from https://www.bbc.com/russian/features-38669895 (In Russian).

Kant, I. (2009). Critique of the power of judgment (P. Guyer \& E. Matthews, Trans.). Cambridge: Cambridge Univ. Press.

Kovalova, N. (2013). Modern choreographic theater: dance as an "invitation to the Real". Arkadiya, (1), 22-26. (In Russian).

Kovalova, N., \& Levchenko, V. (2016). Immersibility as the mechanism of new artistic reality creating. In $\triangle o ́ \xi \alpha / Д о к с а . \triangle o ́ \xi \alpha /$ Doxa. Collected Scientific Articles on the Philosophy and the Philology: Vol. 2: The humanities discourse: diciplinarity, interdiciplinarity, transdiciplinarity (pp. 173-183). Odesa: Akvatoriya. (In Russian).

Levchenko, V. (2017).In search of himself: about the characteristic features of the opera heritage of W. A. Mozart. In ó $\xi \alpha$ / Doxa. Collected Scientific Articles on the Philosophy and the Philology: Vol. 2: Memory and oblivion (pp. 173-182). Odesa: Akvatoriya. (In Russian).

Mozart, W. A. (1966). The Letters of Mozart and his Family. In E. Anderson (Ed.), The Letters of Mozart and his Family. London: Palgrave Macmillan UK. doi: 10.1007/978-1-349-10654-7_1

Ortega y Gasset, J. (1972). The Dehumanization of Art. In The Dehumanization of Art and Other Essays on Art, Culture, and Literature (pp. 65-83). Princeton: Princeton University Press.

Raskin, V. (1984). Semantic mechanisms of humor. Dordrecht; Boston; Lancaster: D. Reidel Publishing Company.

Ricoeur, P. (1992). Oneself as another (K. Blamey, Trans.). Chicago: University of Chicago Press.

Samohvalova, A. (2011). The phenomenon of the absurd theater on the music scene. Opera A. Schnittke "Life with an Idiot" (PhD Thesis). Moscow. (In Russian).

Serkova, N. (2019). Prohibited Reception. About aura and pornography of art. Art magazine, (108). Retrieved from http://moscowartmagazine.com/issue/89 (In Russian).

Sontag, S. (2013). Against Interpretation and Other Essays. New York: Farrar, Straus and Giroux.

Starobinsky, Zh. (2002). Enlightenment and Power in the "Magic Flute". In Poetry and knowledge. History of literatury and cultury (Vol. 2, pp. 445-460). Moscow: Languages of Slavic Culture. (In Russian).

Yampolsky, M. (2015, June 19). "There is no art; there are various anthropological practices of comprehending the world." Interview on the boundaries of art, the forms of its legitimation and the end of a large style. Retrieved from Postscience website: https://postnauka.ru/talks/48454 (In Russian). 


\section{Список литературы}

Artaud, A. (1994). The Theater and Its Double. New York: Grove Press.

Attardo, S. (2001). Humorous Texts: A Semantic and Pragmatic Analysis. New York: Mouton de Gruyter.

Bakhtin, M. (1968). Rabelais and His World Cambridge (I. Iswolsky, Trans.). Bloomington: Indiana University Press.

Bergson, A. (2005). Laughter, an essay on the meaning of the comic. London: Dover Publications.

Betti, E. (2017). Chapter 7: Interpretation of Drama \& Music. In General Theory of Interpretation. London: Createspace Independent Publishing Platform.

Bourdieu, P. (1991). Le champ littéraire [Literary field]. Actes de la Recherche en Sciences Sociales, 89(1), 3-46. doi: 10.3406/arss.1991.2986 (In French).

Camus, A. (1955). The Myth of Sisyphus and Other Essays (J. O'Brien, Trans.). Retrieved from https://postarchive.files.wordpress.com/2015/03/myth-of-sisyphus-and-other-essays-thealbert-camus.pdf

Eco, U. (1984). Postscript to The name of the rose. San Diego, New York and London: Harcourt Brace Jovanovich.

Gadamer, H.-G. (2006). Truth and Method. London and New York: Sheed \& Ward Ltd and the Continuum Publishing Group.

Kant, I. (2009). Critique of the power of judgment (P. Guyer \& E. Matthews, Trans.). Cambridge: Cambridge Univ. Press.

Mozart, W. A. (1966). The Letters of Mozart and his Family. In E. Anderson (Ed.), The Letters of Mozart and his Family. London: Palgrave Macmillan UK. doi: 10.1007/978-1-349-10654-7_1

Ortega y Gasset, J. (1972). The Dehumanization of Art. In The Dehumanization of Art and Other Essays on Art, Culture, and Literature (pp. 65-83). Princeton: Princeton University Press.

Raskin, V. (1984). Semantic mechanisms of humor. Dordrecht; Boston; Lancaster: D. Reidel Publishing Company.

Ricoeur, P. (1992). Oneself as another (K. Blamey, Trans.). Chicago: University of Chicago Press.

Sontag, S. (2013). Against Interpretation and Other Essays. New York: Farrar, Straus and Giroux.

Борисов, Е. (2006). Предисловие к публикации «Герменевтики как общей методологии наук о

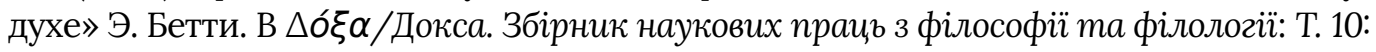
Стратегії інтерпретації тексту: методи і межи їх застосування (сс. 361-367). Одесса: ОНУ ім. І. І. Мечникова.

Грицанов, А. (2001). Трансгрессия. В Постлодернизм. Энциклопедия (с. 842). Минск: Интерпрессерсвис; Книжный Дом.

Кан, А. (2017). Le Grand Macabre-Опера для эпохи Трампа. ВBC News Русская служба. Извлечено от https://www.bbc.com/russian/features-38669895

Ковалева, Н. (2013). Современный хореографический театр: Танец как «приглашение к Реальному». Аркадия, (1), 22-26.

Ковалева, Н., \& Левченко, В. (2016). Иммерсивность как механизм создания новой художе-

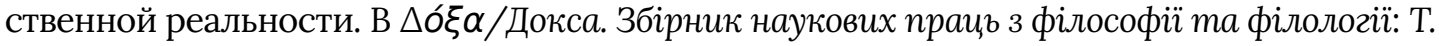


2: Гуманітарний дискурс: дисціплінарність, міждисціплінарність, трансдисиіплінарність (сс. 173-183). Одеса: Акваторія.

Левченко, В. (2017). В поисках себя: О характерных признаках оперного наследия В. А. Моцарта.

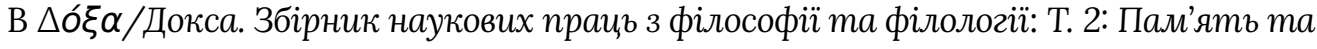
забуття (сс. 173-182). Одеса: Акваторія.

Самохвалова, А. (2011). Феномен театра абсурда на музыкальной сцене. Опера А. Шнитке «Жизнъ с идиотом» (Диссертация на соискание ученой степени кандидата наук). Москва.

Серкова, Н. (2019). Запрещенный прием. Об ауре и порнографии искусства. Художественный журнал, (108). Извлечено от http://moscowartmagazine.com/issue/89

Старобинский, Ж. (2002). Просвещение и власть в «Волшебной флейте». В Поэзия и знание. История литературы и культуры (Т. 2, сс. 445-460). Москва: Языки славянской культуры.

Ямпольский, М. (2015, июнь 19). «Никакого искусства не существует, есть разные антропологические практики постижения мира». Интервью о границах искусства, формах его легитимации и конце большого стиля. Извлечено от Постнаука website:

https://postnauka.ru/talks/48454 